crop in $300-400$ B.c. Gerarde referred to several kinds of round-seeded pea at the end of the sixteenth century. It was not, however, until nearly two centuries later that Thomas Andrew Knight introduced the sweeter and more palatable varieties with wrinkled seeds. Searlet runner beans were introduced from unknown antiquity in South America in 1633. Broad beans came from the East, their use there being of great known antiquity. The tomato was brought to Europe in the fifteenth century, but it has only been improved and attained popularity within the lifetime of our elders. Mr. Giles demonstrated the close affinity of various Brassicas with the wild $B$. oleracec by crosses, which all produced fertile hybrids of great morphological variability, but only incipient hort icultvral promise.

\section{New Contagious Disease in the United States}

A NEw contagious disease with symptoms so mild the sickness may go unnoticed has recently been reported by Dr. Carl H. Smith, of Cormell University Medical College and the New York Hospital. The chief feature of the disease is an increase in the lymphocytes of the blood. Although the number of these white cells may be increased almost ten-fold, they are not abnormal. Fever and vomiting, pain in the back of the head and neck, or pain in the abdomen suggestive of appendicitis may occur in this new disease, but when they do, these symptoms last only a few days. In one case Dr. Smith reports, the child had fever, vomiting and abdominal pain, but a brother and sister had only symptoms of a mild cold. Only since 1939 have cases of this disease, called acute infectious lymphocytosis, been reported. The cause has not been identified, but is believed to be a virus. The disease apparently attacks young children chiefly, and they all seem to recover.

\section{Use of Inter-city Telephone Circuit for Television}

AcCording to a recent announcement by the American Telephone and Telegraph Company (Bell Lab. Rec., 22, No. 9; May 1944) plans have keen made for the construction of a large amount of coaxial cable to ke operated by radio relays. Tentatively, the coaxial extension plans call for the installation of $6,000-7,000$ route miles of coaxial facilities in the next five or six years to help meet expected increasing demands for long-distance telephons service. These facilities would be suitable for interconnecting television stations for network operations. Work on the 295-mile Atlanta to Jacksonville route is in progress, and is expected to be in service for telephone purposes by the spring of 1945. Present coaxial equipment will provide television channels of $2,700,000$ cycles in width. Tests have shown this equipment capable of transmitting the visual images with satisfactory clearness. Further technical improvements will make it possible to use a much wider band of frequencies, which will permit simultaneous use of the same coaxial for an improved $(4,000,000$ cycles $)$ television channel and a large number of telephone messages.

The New York-Philadelphia cable, containing two coaxials, was installed in 1936 for furtker experiment. Its use for transmitting visual images for television broadcasts was first demonstrated in 1937. The cable recently has been providing telephone circuits. The first commercial installation was the Stevens Point-Minneapolis cable, containing four coaxials, two being in regular use and two in 'stand-by' use.
This is capable of providing 480 telephone circuits with its present amplifiers. It is now equipped to handle nearly a hundred circuits and soon will be stepped up to about 150. One of the cables now in use between Philadelphia and Baltimore and another between Baltimore and Washington contain coaxials which, however, have not yet been equipped for service. The former contains six coaxials and the latter four. As many as six or eight coaxials are likely to be built into some of the new cables. In a six-coaxial cable, for example, with the present amplifying equipment, two coaxials could ke used to provide 480 telephone circuits, another two could provide either two one-way television channels or 480 more telephone circuits, and the others would serve as equipped stand-by circuits to protect both services.

\section{Engineering Research in the U.S.S.R.}

VoL. 1, No. 2 of the Engineering Review (Russian) (dated 1941) contains a collection of papers dealing with the mathematics of stress calculations for rotating disks, springs and conical shells. Other papers in the applied mechanics section describe very large mechanical testing machines and an electrical analogy for the investigation of torsion in bars. The hydrodynamies section has papers on filtration in non-homogeneous soils and the unsteady flow of water in canals. A short summary of each paper is given in English or German.

\section{Marine Water-Tube Boilers}

A series of papers read before the Institution of Naval Architects on May 10, 1944, dealt with the design of water-tube boilers for marine propulsion. Designs and data were submitted by Messrs. Babcock and Wilcox, Ltd., International Combustion Co., Ltd., La Mont Steam Generator, Ltd., and Yarrow and Co., Ltd., for a boiler plant suitable for a ship of 7,500 shaft h.p., using oil fuel. The complete set of papers provides a unique opportunity for direct comparison of the designs of modern boilers which should be of great value to marine engineers.

\section{Announcements}

Prof. J. A. Scotr Watson, agricultural attaché at the British Embassy in Washington, has been appointed to the newly created post of chief education and advisory officer to the Ministry of Agriculture.

AT a recent meeting of the Geological Society of Iondon, it was decided provisionally to admit persons between the ages of eighteen and twenty-three as junior associates. Such junior associates will enjoy most of the facilities offered by the Society, except that they may not attend discussions relating to the management of the Society's affairs, and they will not be entitled to vote at any meeting; they will not continue as junior associates after the close of the calendar year in which they become twentythree.

Mr. W. Bowen, of the Bowen Instrument Co., Ltd., has made a gift of $£ 5,000$ to the Scientific Instrument Manufacturers' Association of Great Britain for the establishment of a fund to provide prizes for the best annual contribution to instrument. research, development or design. 